\title{
Influence of publicly available online wait time data on emergency department choice in patients with noncritical complaints
}

\author{
Amelia Yip, MSc, MD*; Shelley McLeod, MSc*; Andrew McRae, MD, PhD ${ }^{\dagger}$; Bin Xie, PhD*
}

ABSTRACT

Objectives: Increased emergency department (ED) wait times lead to more patients who leave without being seen and decreased patient satisfaction. Many EDs post estimated wait times either online or in the ED to guide patient expectations. The objectives of this study were to assess patients' awareness of online wait time data and to investigate patients' willingness to use this information when choosing between two academic EDs in London, Ontario.

Methods: A prospective study was conducted over a 2month period in a tertiary ED with online available wait times. Patients over 18 years of age assigned a Canadian Triage and Acuity Scale (CTAS) score of 3,4 , or 5 were approached by trained research assistants to complete a 15item paper-based questionnaire. Multivariable logistic regression models were used to determine factors independently associated with the outcomes.

Results: A total of 1,211 patients completed the survey. Of these, $109(9 \%)$ were aware that ED wait time information was available on the Internet; $544(45 \%)$ reported that they would use the available data to make a decision on which ED to visit, and $536(44 \%)$ indicated that they were more likely to go to the ED with a shorter wait time. Age, gender, household income, education, and Internet access were not associated with awareness of online ED wait times. Participants less than 40 years of age were more likely to use online wait time information.

Conclusion: There is low awareness of the availability of ED wait time data published online in the study locaton. Future research may include the delivery of a public awareness strategy for ED wait time data and a re-evaluation of ED use and patient satisfaction following this.

\section{RÉSUMÉ}

Objectifs: L'allongement du délai d'attente dans les services d'urgence a pour conséquences une augmentation du nombre de patients non vus et une diminution du degré de satisfaction. Dans de nombreux services d'urgence, on affiche le délai d'attente approximatif, soit en ligne, soit sur les lieux mêmes, pour donner aux patients une idée du temps d'attente. La présente étude avait pour objectifs d'évaluer dans quelle mesure les patients connaissaient l'existence de données en ligne sur les délais d'attente, et de vérifier si les patients étaient disposés à utiliser ces renseignements pour faire un choix entre deux services d'urgence universitaires à London, en Ontario.

Méthodes: Une étude prospective a été menée sur une période de 2 mois, dans un service d'urgence de soins tertiaires, qui affichait en ligne le délai d'attente. Des patients âgés de plus de 18 ans, ayant obtenu une cote de 3,4 , ou 5 sur l'Échelle canadienne de triage et de gravité ont été rencontrés par des adjoints à la recherche formés à cet effet, pour remplir le questionnaire sur papier, en 15 points. Nous avons appliqué ensuite des modèles de régression logistique à plusieurs variables pour dégager des facteurs indépendants des résultats.

Résultats: Au total, 1,211 patients ont rempli le questionnaire. Sur ce nombre, 109 (9\%) savaient que le délai d'attente, à l'urgence, était affiché dans Internet; 544 (45\%) ont fait savoir qu'ils tiendraient compte des données fournies pour choisir une urgence plutôt qu'une autre; et 536 (44\%) ont indiqué qu'ils iraient à l'urgence lorsque le délai d'attente serait plus court. L'âge, le sexe, le revenu du ménage, le niveau d'instruction, et l'accès à Internet n'étaient pas des facteurs associés à la connaissance de l'affichage en ligne du délai d'attente à l'urgence. Les participants de moins de 40 ans étaient plus susceptibles d'utiliser le service en ligne pour connaître le délai d'attente.

Conclusion: Dans le service à l'étude, peu de personnes connaissaient l'existence des données en ligne sur le délai d'attente à l'urgence. D'autres études pourraient porter sur la mise en oeuvre d'une stratégie de sensibilisation du public à l'égard de l'affichage de ces données et, par la suite, avoir pour objet une réévaluation de l'utilisation des

From the *Schulich School of Medicine and Dentistry, Western University, London, ON; ${ }^{\dagger}$ Division of Emergency Medicine, Calgary University, Calgary, AB.

See the related editorial by Eric Grafstein, MD, in this issue.

Correspondence to: Shelley McLeod MSc, BSc, Division of Emergency Medicine, Department of Medicine, Western University, London, ON N6A 5W9; shelley.mcleod@Ihsc.on.ca.

This article has been peer reviewed.

(c) Canadian Association of Emergency Physicians

CJEM 2012;11(4):237-246

DOI $10.2310 / 8000.2012 .120601$
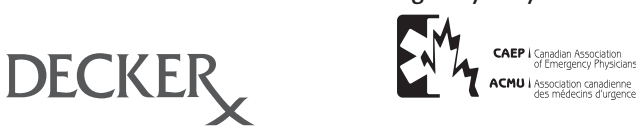
services à l'urgence et du degré de satisfaction des patients.
Keywords: emergency department wait time, noncritical illnesses, online wait time data, patient perception, patient satisfaction
Strategies to reduce Canadian emergency department (ED) wait times have typically focused on decreasing the amount of time patients spend waiting for an initial assessment by an emergency physician and the time admitted patients spend in the ED waiting for an inpatient bed. ${ }^{1}$ Publication of ED wait time data is performed by a number of provincial ministries of health to demonstrate the success of wait time reduction strategies. In Ontario, a dedicated website, managed by the Ministry of Health and Long-Term Care, provides wait time data for over 90\% of the province's EDs (126 hospitals in total). ${ }^{2}$ The published data are an average of the previous month's ED admissions and can be compared to provincial standards as a metric of ED efficiency.

If online ED wait time information were updated more frequently or existed in real time and public awareness was high, the availability of such information could have broad implications. For example, in communities with multiple ED options, patients might use published wait time information to select the site with a shorter wait time, potentially reducing the use of sites with longer wait times. In communities with alternatives to the ED for the care of minor problems, such as walk-in clinics or urgent care centres, publication of ED wait time information could also influence patients' choice of care location among the available options. This possibility is particularly important in a jurisdiction with universal health care such as Canada, where the ability to pay is not typically an issue affecting patients' choice of health care provider.

The objectives of this study were to assess patients' awareness of online wait time data and to investigate patients' willingness to use this information when choosing between two academic EDs in London, Ontario. In addition, we evaluated associations between patients' clinical and demographic characteristics and these two outcomes that might guide strategies to enhance the utility of online wait time data.

\section{METHODS}

\section{Study design and setting}

This prospective study was conducted during April and May 2010 in the ED of Victoria Hospital in London,
Ontario, an academic tertiary care centre affiliated with The University of Western Ontario with an annual ED census of 65,000. London has two adult EDs located 8.5 kilometers apart that serve a catchment population of approximately 500,000 persons. The two EDs are part of the London Health Sciences Centre (LHSC) and are staffed by the same group of 43 emergency physicians.

All patients over 18 years of age assigned a Canadian Triage and Acuity Scale (CTAS) ${ }^{3}$ score of 3, 4, or 5 were approached by trained research assistants and invited to complete a 15 -item paper-based questionnaire. Patients were excluded if they arrived by ambulance, were cognitively impaired, did not read or speak English, or had a presenting complaint that was psychiatric in nature. Individuals who were deemed by the research assistant to be too physically or mentally ill or who were directly referred to a specialty service were also excluded. Participation was voluntary and anonymous, and informed consent was obtained. Approval for this research study was obtained from the Health Sciences Research Ethics Board at The University of Western Ontario.

Beginning in February 2009, daily updates of the average wait times for the two EDs of LHSC were provided online to the public on the LHSC website. ${ }^{4}$ The LHSC website provides two types of ED wait time information, both in hours: the average length of stay for patients who were treated in the ED and discharged and the average length of stay for ED patients who were admitted to hospital for further treatment. Both online wait times refer to the previous day and are not real-time data.

Participants were asked demographic information and questions related to their accessibility to the Internet, the reason for their ED visit, their existing knowledge regarding published local ED wait times, and their motivation for choosing the specific ED for their health care needs. The survey questions were created by the investigators after a review of the relevant literature and consultation with emergency residents, physicians, and an epidemiologist. Prior to distribution, the questionnaire was pilot tested for language and ease of comprehension. All surveys were completed by the participants while they waited to be seen by an emergency physician. The research 
assistants screened for eligible patients and distributed and collected all questionnaires. The full questionnaire can be viewed in the online version of this article at .

\section{Data analysis}

To estimate the sample size required to achieve $80 \%$ power and a desired precision level of $5 \%$, we used the formula of Peduzzi and colleagues, ${ }^{5} N=10 \mathrm{k} / \mathrm{p}$, where $\mathrm{p}$ is the estimated proportion of patients who would use wait time information in the selection of an ED and $\mathrm{k}$ is the number of covariates included in regression models. We estimated that $10 \%$ of patients would use wait time information in the selection of ED site and expected to model 10 covariates. From this, we estimated that 1,000 patients needed to complete the questionnaire and increased our sample size target by an additional $10 \%$ to account for potential missing data from the questionnaire.

Data were entered directly into a study-specific Microsoft Excel database (Microsoft Corporation, Redmond, WA). Standard descriptive statistics were used. The primary outcomes were awareness of available online ED wait times and willingness to use this information when choosing an ED. Bivariate relationships between the CTAS score and demographic data collected in the survey (age, gender, household income, education level, and home Internet access) and the outcomes of interest were assessed using the Pearson chi-square $\left(\chi^{2}\right)$ test. Multivariable logistic regression modeling was used to evaluate the same predictor variables association with the outcomes. All analyses were performed using $\mathrm{R}$ version $2.12 .0 .^{6}$

\section{RESULTS}

A total of 1,211 patients completed the questionnaire. Table 1 provides the characteristics of the study participants and their ED visits. Thirty-five percent of participants indicated that they had "bad" or "very bad" experiences with ED wait time, and 33\% indicated that they had "neutral" experiences. Awareness of published LHSC ED wait time information was low (9\%), after 6 months of the availability of such information. Although only 21 participants (2\%) stated that online wait time information was the reason they chose the ED site to visit, $45 \%$ of the study population indicated that they would use the ED wait time information if they knew it was available, $44 \%$ indicated a willingness to base their ED site decision on published wait time data, and $44 \%$ indicated that they were likely or very likely to choose an alternative ED if the wait time of that ED was known to be shorter. Thirty-four percent of participants indicated that they would be willing to switch their choice of an ED for a wait time difference less than 1 hour, and an additional $34 \%$ indicated that they would do so if a difference between 1 and 2 hours existed.

Table 2 provides the bivariate relationships between the outcome variables and the covariates, and Table 3 provides the results of the multivariate logistic regression models. The only variable that was significantly associated with awareness of the published ED wait time information was education. Respondents who completed high school were less likely than those who had a college, university, or graduate degree to be aware of the online ED wait time information (OR 0.57, 95\% CI $0.32-0.97)$. Willingness to use the available information differed across age groups and with the availability of Internet access. Younger participants and those with Internet access were more likely to indicate willingness to use online ED wait time information. However, after adjusting for other covariates, the relationship between availability of Internet access and willingness to use wait time information was not found to be significant. The relationship between age group and willingness to use available $\mathrm{ED}$ wait time information remained significant on multivariate analysis. Compared to those aged between 18 and 39 years, participants between 40 and 60 years indicated that they were $35 \%$ less likely to use ED wait time information, and those over 60 years indicated that they were $37 \%$ less likely to use such information.

\section{DISCUSSION}

This study assessed patients' awareness of online available ED wait time data and their stated willingness to use this information when choosing an ED in London, Ontario. A large proportion of patients indicated a willingness to use online available wait time information to choose between ED sites. Despite ED wait time information being available online for 6 months prior to the initiation of the study, over $90 \%$ of respondents were unaware that access to such information existed.

Although a number of institutions across North America provide ED wait time information, ${ }^{3,7,8}$ we are unaware of any previous studies evaluating patients' awareness of or willingness to use such information. 


\begin{tabular}{|c|c|}
\hline Characteristic & $n$ \\
\hline Mean age, yr & 40 (SD 17) \\
\hline \multicolumn{2}{|l|}{ Age group, yr } \\
\hline 18-39 & $691(57 \%)$ \\
\hline $40-59$ & $331(27 \%)$ \\
\hline$\geq 60$ & $166(14 \%)$ \\
\hline Unknown & $23(2 \%)$ \\
\hline \multicolumn{2}{|l|}{ CTAS } \\
\hline 3 (urgent) & $486(40 \%)$ \\
\hline 4 (less urgent) & $663(55 \%)$ \\
\hline 5 (nonurgent) & $27(2 \%)$ \\
\hline Unknown & $35(3 \%)$ \\
\hline \multicolumn{2}{|l|}{ Gender } \\
\hline Female & $661(55 \%)$ \\
\hline Male & $550(45 \%)$ \\
\hline \multicolumn{2}{|l|}{ Household income } \\
\hline$\leq 25,000$ & $301(25 \%)$ \\
\hline $25,000-49,999$ & $272(22 \%)$ \\
\hline $50,000-99,999$ & $245(20 \%)$ \\
\hline$\geq 100,000$ & $103(9 \%)$ \\
\hline Choose not to answer & $290(24 \%)$ \\
\hline \multicolumn{2}{|l|}{ Education } \\
\hline Not completed high school & $218(18 \%)$ \\
\hline Completed high school & $328(27 \%)$ \\
\hline College/university/graduate degree & $483(40 \%)$ \\
\hline Other & $50(4 \%)$ \\
\hline Unknown & $132(11 \%)$ \\
\hline \multicolumn{2}{|l|}{ Internet access } \\
\hline No & $381(31 \%)$ \\
\hline Yes & $830(69 \%)$ \\
\hline \multicolumn{2}{|l|}{ Arrival } \\
\hline By foot & $38(3 \%)$ \\
\hline Private vehicle & 1099 (91\%) \\
\hline Public transit & $42(4 \%)$ \\
\hline Other & $32(3 \%)$ \\
\hline \multicolumn{2}{|l|}{ Reason for ED visit } \\
\hline Fever/cough/short of breath & $59(5 \%)$ \\
\hline Chest pain/palpitations & $61(5 \%)$ \\
\hline Problems of the digestive system & $238(20 \%)$ \\
\hline Injury/fall/traffic accident & $149(12 \%)$ \\
\hline Other & $704(58 \%)$ \\
\hline \multicolumn{2}{|l|}{ Reason for choosing this ED } \\
\hline Shorter wait time based on website & $21(2 \%)$ \\
\hline Shorter wait time based on experience & $32(3 \%)$ \\
\hline More convenient/shorter distance & $607(50 \%)$ \\
\hline Always come to this site & $159(13 \%)$ \\
\hline My specialist works here & $122(10 \%)$ \\
\hline Like the doctors/nurses here & $66(5 \%)$ \\
\hline No particular reason/other reasons & $185(15 \%)$ \\
\hline Unknown & $19(2 \%)$ \\
\hline
\end{tabular}

\begin{tabular}{|c|c|}
\hline Characteristic & $n$ \\
\hline Mean age, yr & 40 (SD 17) \\
\hline \multicolumn{2}{|l|}{ Day of week } \\
\hline Weekdays & $889(73 \%)$ \\
\hline Weekend & $277(23 \%)$ \\
\hline Unknown & $45(4 \%)$ \\
\hline \multicolumn{2}{|l|}{ Time of day } \\
\hline Daytime & $368(30 \%)$ \\
\hline Early evening & $784(65 \%)$ \\
\hline Unknown & $59(5 \%)$ \\
\hline \multicolumn{2}{|c|}{ Aware of the information } \\
\hline Yes & 109 (9\%) \\
\hline No & $1078(89 \%)$ \\
\hline Unknown & $24(2 \%)$ \\
\hline \multicolumn{2}{|l|}{ Will use if aware } \\
\hline Yes & $544(45 \%)$ \\
\hline No & $529(44 \%)$ \\
\hline Unknown & $138(11 \%)$ \\
\hline \multicolumn{2}{|c|}{ Will go to another ED if wait shorter } \\
\hline Very unlikely & $124(10 \%)$ \\
\hline Unlikely & $188(15 \%)$ \\
\hline Not sure & $274(23 \%)$ \\
\hline Likely & $269(22 \%)$ \\
\hline Very likely & $267(22 \%)$ \\
\hline Unknown & $89(7 \%)$ \\
\hline \multicolumn{2}{|c|}{ Experiences with wait time in London } \\
\hline Very bad & $132(11 \%)$ \\
\hline Bad & $294(24 \%)$ \\
\hline Neutral & $405(33 \%)$ \\
\hline Good & $217(18 \%)$ \\
\hline Very good & $52(4 \%)$ \\
\hline Unknown & $111(9 \%)$ \\
\hline \multicolumn{2}{|c|}{$\begin{array}{l}\text { Likelihood of choosing alternative ED if wait time } \\
\text { in alternative ED is known to be shorter }\end{array}$} \\
\hline Very likely & $267(22 \%)$ \\
\hline Likely & $269(22 \%)$ \\
\hline Not sure & $274(23 \%)$ \\
\hline Unlikely & $188(16 \%)$ \\
\hline Very unlikely & $125(10 \%)$ \\
\hline Unknown & $88(7 \%)$ \\
\hline \multicolumn{2}{|c|}{$\begin{array}{l}\text { How much shorter does the wait time in } \\
\text { alternative ED have to be for you to switch? }\end{array}$} \\
\hline$\leq 1$ hour & $414(34 \%)$ \\
\hline $1-2$ hours & 406 (34\%) \\
\hline 2-3 hours & $153(13 \%)$ \\
\hline 3-4 hours & 31 (3\%) \\
\hline$>4$ hours & $34(3 \%)$ \\
\hline Unknown & $173(14 \%)$ \\
\hline
\end{tabular}




\begin{tabular}{|c|c|c|c|c|c|c|}
\hline & $\begin{array}{c}\text { Aware of the } \\
\text { information } n(\%)\end{array}$ & $\begin{array}{l}\text { Unaware of the } \\
\text { information } n(\%)\end{array}$ & $\begin{array}{l}p \text { value } \\
\text { for } \chi^{2}\end{array}$ & $\begin{array}{l}\text { Will use if } \\
\text { aware } n(\%)\end{array}$ & $\begin{array}{l}\text { Will not use if } \\
\text { aware } n(\%)\end{array}$ & $\begin{array}{l}p \text { value } \\
\text { for } \chi^{2}\end{array}$ \\
\hline \multicolumn{7}{|l|}{ Age group } \\
\hline 18-39 & $58(55)$ & $624(59)$ & 0.57 & $356(66)$ & $275(53)$ & $<0.001$ \\
\hline $40-59$ & $34(32)$ & $289(27)$ & & $127(24)$ & $163(31)$ & \\
\hline$\geq 60$ & $14(13)$ & $146(14)$ & & $53(10)$ & 80 (15) & \\
\hline \multicolumn{7}{|l|}{ Gender } \\
\hline Female & $62(57)$ & $585(54)$ & 0.67 & $283(52)$ & $300(57)$ & 0.14 \\
\hline Male & $47(43)$ & $493(46)$ & & $261(48)$ & $229(43)$ & \\
\hline \multicolumn{7}{|l|}{ Household income } \\
\hline$\leq 25,000$ & $22(20)$ & $271(25)$ & 0.48 & $150(28)$ & $129(24)$ & 0.16 \\
\hline $25,000-49,999$ & $25(23)$ & $239(22)$ & & $116(21)$ & $123(23)$ & \\
\hline $50,000-99,999$ & $23(21)$ & $221(20)$ & & $124(23)$ & 98 (19) & \\
\hline$\geq 100,000$ & $14(13)$ & $89(8)$ & & $46(8)$ & $52(10)$ & \\
\hline Choose not to answer & $25(23)$ & $258(24)$ & & $108(20)$ & $127(24)$ & \\
\hline \multicolumn{7}{|l|}{ Education } \\
\hline Not completed high school & $15(16)$ & $198(20)$ & 0.06 & $91(18)$ & $105(22)$ & 0.10 \\
\hline Completed high school & $20(21)$ & $303(31)$ & & $152(31)$ & $143(30)$ & \\
\hline $\begin{array}{l}\text { College/university/ } \\
\text { graduate degree }\end{array}$ & $54(58)$ & $420(43)$ & & $236(48)$ & $198(42)$ & \\
\hline Other & $4(4)$ & $45(45)$ & & $17(3)$ & $27(6)$ & \\
\hline \multicolumn{7}{|l|}{ Internet access } \\
\hline No & $34(31)$ & 334 (31) & 0.95 & $144(26)$ & $179(34)$ & 0.01 \\
\hline Yes & $75(69)$ & $744(69)$ & & $400(74)$ & $350(66)$ & \\
\hline \multicolumn{7}{|l|}{ CTAS } \\
\hline 3 & $48(44)$ & $429(40)$ & 0.73 & $208(38)$ & 227 (43) & 0.49 \\
\hline 4 & $56(51)$ & $594(55)$ & & $307(56)$ & $276(52)$ & \\
\hline 5 & $3(3)$ & $23(2)$ & & $12(2)$ & $11(2)$ & \\
\hline Unknown & $2(2)$ & $32(3)$ & & $17(3)$ & $15(3)$ & \\
\hline
\end{tabular}

The low awareness of wait time information availability among study participants was not surprising considering that there was no advertising or start-up campaign to educate the public. Our results suggest that without such efforts, simply posting ED wait times online results in very low public awareness. The fact that nearly half of the participants indicated a willingness to use online wait time data when selecting an ED suggests that increasing public awareness may be beneficial to the uptake and utility of such information.

In this study, younger patients were more likely to indicate a willingness to use Web-based ED wait time information. Considering that the majority of health care resources are consumed by patients over the age of 65 in the United States, ${ }^{910}$ and by patients under 5 and over 60 years in Canada, ${ }^{11}$ Web-based dissemination of wait time information may not reach the largest group of ED users. Supplementation with different media, such as print, radio, and television advertisements, may increase public awareness and the use of wait time information by those who are most likely to seek emergency health care. In the United States, the dissemination of ED wait time information has been done through public notices, billboards, and websites. ${ }^{12}$ Health care corporations that have chosen to publish their data on websites similarly notified the public of these websites through television, radio, and newspaper advertisements; billboards; and press conferences. ${ }^{12}$

Overcrowding and lengthy ED wait times are challenges facing many locations in Canada. Given our aging population and current economic environment, the situation is unlikely to improve in the near future. Patients' stated willingness to use wait time information to select an ED site suggests that providing such information may be one strategy to decrease lengthy wait times for patients with less acute health problems. Although the volume of low-acuity patients is not the root cause of ED overcrowding, ${ }^{1}$ the ability of 


\begin{tabular}{|c|c|c|c|c|}
\hline & \multicolumn{2}{|c|}{ Aware of the information $(n=1,040)$} & \multicolumn{2}{|c|}{ Will use if aware ( $n=953$ ) } \\
\hline & OR $(95 \% \mathrm{Cl})$ & $p$ value & OR $(95 \% \mathrm{Cl})$ & $p$ value \\
\hline \multicolumn{5}{|l|}{ Age group } \\
\hline 18-39 & 1.00 & & 1.00 & \\
\hline $40-59$ & $1.25(0.75-2.05)$ & 0.39 & $0.65(0.47-0.88)$ & 0.006 \\
\hline$\geq 60$ & $1.35(0.66-2.58)$ & 0.39 & $0.63(0.41-0.95)$ & 0.03 \\
\hline \multicolumn{5}{|l|}{ Gender } \\
\hline Female & 1.00 & & 1.00 & \\
\hline Male & $1.00(0.64-1.55)$ & 0.99 & $1.21(0.93-1.57)$ & 0.16 \\
\hline \multicolumn{5}{|l|}{ Household income } \\
\hline$\leq 25,000$ & 1.00 & & 1.00 & \\
\hline $25,000-49,999$ & $1.25(0.65-2.44)$ & 0.51 & $0.86(0.59-1.24)$ & 0.41 \\
\hline $50,000-99,999$ & $1.26(0.64-2.50)$ & 0.51 & $1.13(0.77-1.67)$ & 0.53 \\
\hline$\geq 100,000$ & $1.31(0.54-3.01)$ & 0.53 & $0.85(0.50-1.43)$ & 0.53 \\
\hline Choose not to answer & $1.18(0.60-2.34)$ & 0.63 & $0.85(0.58-1.24)$ & 0.40 \\
\hline \multicolumn{5}{|l|}{ Education } \\
\hline Not completed high school & $0.62(0.31-1.17)$ & 0.15 & $0.78(0.54-1.12)$ & 0.18 \\
\hline Completed high school & $0.57(0.32-0.97)$ & 0.04 & $0.86(0.63-1.17)$ & 0.33 \\
\hline College/university/graduate degree & 1.00 & & 1.00 & \\
\hline Other & $0.75(0.21-2.01)$ & 0.60 & $0.56(0.28-1.08)$ & 0.09 \\
\hline \multicolumn{5}{|l|}{ Internet access } \\
\hline No & $0.78(0.42-1.38)$ & 0.41 & $0.80(0.57-1.11)$ & 0.18 \\
\hline Yes & 1.00 & & 1.00 & \\
\hline \multicolumn{5}{|l|}{ CTAS } \\
\hline 3 & 1.00 & & 1.00 & \\
\hline 4 & $0.79(0.50-1.25)$ & 0.31 & $1.27(0.96-1.68)$ & 0.09 \\
\hline 5 & $1.63(0.37-5.19)$ & 0.45 & $1.16(0.47-2.89)$ & 0.74 \\
\hline Unknown & $0.63(0.10-2.23)$ & 0.54 & $1.11(0.52-2.37)$ & 0.79 \\
\hline
\end{tabular}

such patients to choose between ED sites may reduce wait times for this group. For example, one strategy would be to publish ED wait time information that includes wait time information for alternative health care providers such as walk-in clinics or urgent care centres targeted at patients with conditions suitable for such providers. This may divert a proportion of patients with conditions that could be managed elsewhere and thus positively impact ED overcrowding.

Online publication of ED wait times may have a positive impact on wait times for low-acuity conditions. However, several potential problems may arise and need to be addressed before such a practice is implemented in a widespread manner. For example, too many patients responding to published wait time information and selecting the ED with the shorter wait time may actually lead to overcrowding and lengthen wait times for that site. Moreover, published wait times may influence patient expectations and, if such expectations are not met, may negatively influence patient satisfaction. These concerns highlight the need for timely updating of published ED wait time information to ensure appropriate patient self-triage and to create realistic expectations.

This study has limitations. First, the survey was distributed in a single adult ED, and as such, the results may not be generalizable to other communities. Additional research in other communities and pediatric EDs would provide further information on the generalizability of our findings. Second, we excluded patients with a CTAS score of 1 (resuscitation) or 2 (emergent) and patients transported to the ED by ambulance as these patients would be unlikely to rely on published wait time information to select an ED site. Given that published ED wait time information is not intended for use by these patients, the exclusion of these patients did not negatively impact the validity of our findings. Third, this study took 
place over 2 months in the spring. It is possible that unknown or secular factors (such as winter, bad weather, or traffic conditions) may affect patient choice of ED sites, so the published wait times may become more or less important in the patient's choice of ED sites when such factors change. Nevertheless, we still expect our conclusion that published wait times is an important factor in patient's choice of ED sites to remain true given the large proportion of patients who indicated a willingness to use such information to choose ED sites. Finally, we did not investigate alternative reasons behind patients' decision to select one ED over another. Over half of our study participants made (or indicated that they would make if aware of wait time information) an ED site selection based on reasons other than wait time, and further research on this would augment the results from this study.

\section{CONCLUSIONS}

There is low awareness of the availability of ED wait time data published online in the study locaton. Future research may include the delivery of a public awareness strategy for ED wait time data and a re-evaluation of ED use and patient satisfaction following this.

Competing interests: None declared.

\section{REFERENCES}

1. Canadian Association of Emergency Physicians. Taking action on the issue of overcrowding in Canada's emergency departments. 2005. Available at: http://www.waittimealliance. ca/waittimes/CAEP.pdf (accessed February 17, 2011).

2. Ontario Ministry of Health and Long-Term Care website. Available at: http://waittimes.hco-on.ca/EN/search/er/ (accessed Feb 2011).

3. Murray M, Bullard M, Grafstein E, et al. Revisions to the Canadian Emergency Department Triage and Acuity Scale implementation guidelines. CFEM 2004;6:421-7.

4. London Health Sciences Centre. Emergency department wait times. Available at: http://www.lhsc.on.ca/About_Us/ Accountability/Caring_for_our_Patients/Wait_Times/ED/ (accessed February 17, 2011).

5. Peduzzi P, Concato J, Kemper E, et al. A simulation study of the number of events per variable in logistic regression analysis. F Clin Epidemiol 1996;49:1373-9, doi:10.1016/ S0895-4356(96)00236-3.

6. Development Core Team. A language and environment for statistical computing. Vienna (Austria): Foundation for Statistical Computing; 2010.

7. WESH.com Orlando. New billboards display ER wait times. Available at: http://www.wesh.com/health/20983530/detail. html\# (accessed February 17, 2011).

8. Middlesex Hospital. Emergency room waiting time clock, Available at: http://middlesexertime.com/ (accessed February 17, 2011).

9. US Department of Health and Human Services, Centers for Disease Control and Prevention, National Centre for Health Statistics. Health care in America: trends in utilization. 2004. Washington: US DHHS; 2004. DHHS Pub No. 2004-1031.

10. US Census Bureau. Statistical abstract of the United States. 2011. Available at: http://www.census.gov/compendia/statab/ (accessed Feb 2011).

11. Available at: http://atlas.nrcan.gc.ca/auth/english/maps/health/ servicesutilization/utilization_figure2.gif/image_view (accessed Feb 2011).

12. Gamble KH. Wait watchers: smart organizations are demonstrating that while they can't erase ED wait times, they can leverage technology to keep patients better informed. Healthc Inform 2010;27(4):30-1. 
Yip et al

\section{APPENDIX. A SURVEY ON THE INFLUENCE OF WAIT TIME DATA ON CHOICE OF EMERGENCY DEPARTMENT}

\section{Demographic Data}

1. Please indicate your gender:

Male

Female

2. What is your age? years old

3 What is yearly household income?

$\square \leq \$ 25,000$

$\$ 25,001-\$ 49,999$

$\$ 50,000-\$ 99,999$

$\geq \geq 100,000$

$\square$ Choose not to answer

4. What is the highest level of education you have received?

$\square$ Not completed high school

Some high school

Completed high school

College/university degree

Graduate/advanced degree

Other:

5. Do you have access to the Internet at home or work?

Yes

No

\section{Emergency Department Data}

6. What is the primary reason for your current emergency department visit? (Please check only $\mathrm{ONE}$ )
Headache
Ear problems
Short of breath
Abdominal pain
Urination problems
Numbness/sensory changes
Medication advice
Dizziness/vertigo
Fever
$\square$ Chest pain
$\square$ Vomiting
$\square$ Back/neck pain
Rash/itch/bite
$\square$ Muscle/joint/bone pain
$\square$ Other

$\square$ Eye problems

$\square$ Cough

$\square$ Palpitations

Stool changes

Weakness

Injury/fall

Vehicle/bicycle collision

\section{Emergency Department Location}

7. How did you arrive at this emergency department?

On foot

Driven by self

Driven by other

Driven by taxi

Via public transit

$\square$ Other 
8. Why did you choose this particular emergency department? (Please choose the most important reason. Choose only $\underline{\mathrm{ONE}}$ )

$\square$ I believe that the wait time here would be shorter based on the information posted on London Health Sciences Centre website

$\square$ I believe that the wait time here would be shorter based on past experiences

It's closer to my home/work

It's more convenient to come to this emergency department

$\square$ I've always come to this emergency department

$\square$ My specialist works here (please specify doctor's name:

I like the doctors here better than at the other emergency department

I like the nursing staff here better than at the other emergency department

Word of mouth/reputation

Recommended by family doctor

No specific reason

Other

\section{London Health Sciences Centre (LHSC) Wait Time Website}

9. Did you know that emergency department wait time statistics are published on the LHSC website?

$\square$ Yes

$\square$ No

10. Have you ever been on the LHSC emergency department wait time website?

$\square$ Yes

$\square$ No

11. If yes, did you use the emergency department wait time information from the website when making your choice of emergency department location?

Yes

$\square$ No, why not?

12. If no, and you were given a chance to see the emergency department wait time statistics before coming, would you base your decision on emergency department location on the data you saw on the website?

Yes

No Why not?

Wait Time and Emergency Department Site Selection

13. How would you rate your experiences with wait time in emergency departments in London?

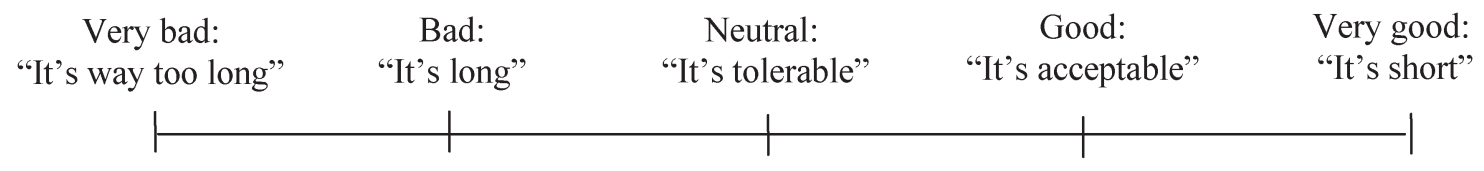

14. If you knew that the wait time in the other emergency department was shorter, how likely is it that you would have go to that department instead of this one?

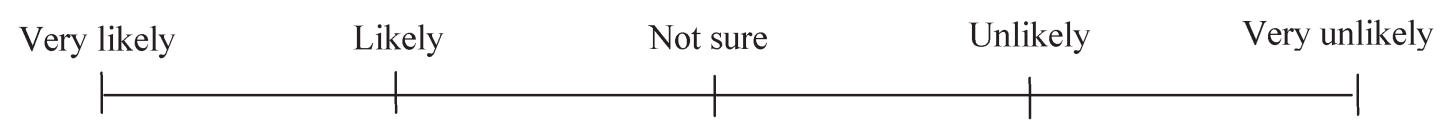


15. If you are willing to travel to an LHSC emergency department with a shorter wait time, how much shorter does the wait have to be for you to travel to the other hospital?
$\leq 1$ hour
$1-2$ hours
2-3 hours
$3-4$ hours
$>4$ hours

This is the end of the survey.

Thank you for your participation

\section{RA Use Only:}

Location:

CTAS:

Date\&Time:

RA:

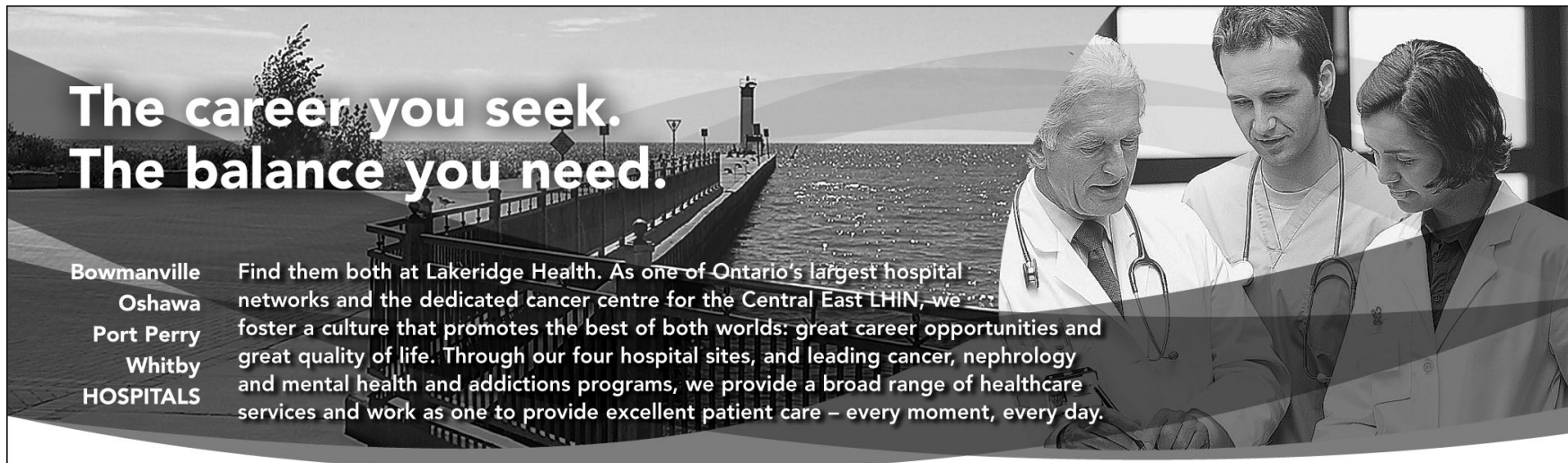

\section{Emergency Medicine Physician}

CCFP EM or FRCP candidates, or those with extensive ER experience, will be interested in this full-time position in our Department of Emergency Medicine and Critical Care, primarily based at Lakeridge Health Oshawa. Physicians enjoy a flexible coverage schedule with generous backup. We offer a comprehensive ED Ultrasound Program with 2 dedicated ED US machines. You must be an experienced physician, be licensed to practise in Ontario, and have ACLS and ATLS certifications. Mentoring is available, as are teaching opportunities.

For more information about us and this opportunity, please visit our website. You may also contact: Dr. Benjamin Fuller, Chief and Medical Director, Department of Emergency Medicine \& Critical Care, Lakeridge Health. Tel: 1-866-703-2072 or 905-576-8711, ext. 3720. E-mail: mdcv@lakeridgehealth.on.ca.

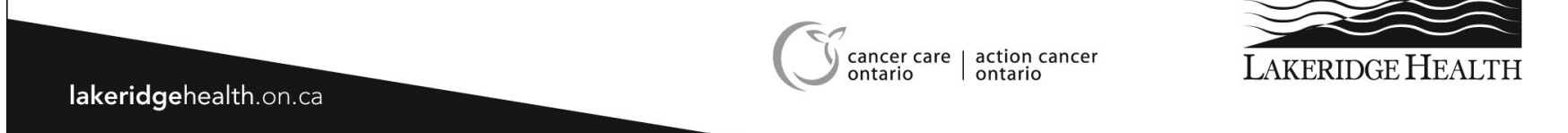

